\title{
Non-word Repetition
}

National Cancer Institute

\section{Source}

National Cancer Institute. Non-word Repetition. NCI Thesaurus. Code C92461.

A measure of linguistic development based on a person's ability to accurately repeat nonsense words. 